\title{
Phaselis Hadrianus Kapısı: Arkeolojik Alanlarda Yerinde Sergilemeye Bir Örnek
}

\author{
Phaselis Hadrian's Gate: \\ A Case Study on in situ Exhibition in Archaeological Fields:
}

\begin{abstract}
Ayça AKÇAY*
$\ddot{\boldsymbol{O}}_{z:}$ Phaselis’te yer alan Hadrianus Kapısı doğa, zaman ve insani faktörler nedeniyle yıkılmış durumda olduğundan bu monümental yapının blokları alanda dağınık halde bulunmakta ve ziyaretçiler tarafından algılanamamaktadır. Bu kapsamda alanın bütüncül bir yaklaşımla sergilenmesi ve ziyaretçilerin yapıyı doğru algılayabilmesi için yerinde sergileme yöntemleri uygulanmıştır. Phaselis Hadrianus Kapısı'nda uygulanan yerinde sergileme yönteminde öncelikle koruma uygulamaları ve belgeleme çalışmaları ele alınmıştır. Bu araştırmalara bağlı uygulamaların kent ölçeğinde, ziyaretçi odaklı bir sergi deneyimine nasıl dönüştüğü, sergileme elemanlarının ve içeriklerinin tasarımı çalışmanın ilerleyen bölümlerinde anlatılmıştır. $\mathrm{Bu}$ çalışmada arkeolojik bir yapının yerinde sergilenmesinde dijital metotlar kullanılarak, iç mimarlık disiplininin barındırdığı estetik, algısal ve boyutsal kavramlarla sentezlenerek kültürel farkındalık yaratılacağı öngörülmüştür. Konunun tasarım disiplinleri içerisinde önemli bir yaklaşım olduğu ve olacağı, ardıl çalışmalarda yeni teknolojik metotlarla daha da geliştirilebileceği ve yeni başlangıçlara, farklı üretimlere referans olacağı sonucuna ulaşılmıştır.
\end{abstract}

Anahtar sözcükler: Yerinde Sergileme, Sergi Tasarımı, Koruma, Phaselis, Hadrianus Kapısı

\begin{abstract}
The Hadrian's Gate located in the Ancient city of Phaselis has been collapsed due to the nature, time and human factors. The blocks of this monumental building are scattered in the area and cannot be perceived by the visitors. In this context, in situ exhibition methods have been applied in order to exhibit the area with a holistic approach and to enable visitors to perceive the structure correctly. During the in situ exhibition method applied to the Phaselis Hadrian's Gate, firstly conservation practices and documentation studies were discussed. The design of the exhibition elements related to these practices and how all these applications turn into a visitor-oriented exhibition experience at the city scale are explained in the study. As a result, it is envisaged that cultural awareness will be created by using digital methods in the in situ exhibition of an archaeological stricture and synthesizing with the aesthetic, perceptual and dimensional concepts of the interior architecture discipline. As a result, it is anticipated that cultural awareness will be created by syntesizing the aesthetic, perceptual and dimensional concepts of the interior architecture discipline by using digital methods in the in situ exhibition of an archaeological structure. It is concluded that the subject has an important role in design disciplines, that it can be further developed with innovative technological methods in successive studies and will be a reference for new beginnings and different productions.
\end{abstract}

Keywords: In situ Exhibition, Exhibition design, Conservation, Phaselis, Hadrian's Gate

\footnotetext{
* M.A., Hacettepe Üniversitesi, Güzel Sanatlar Enstitüsü, İç Mimarlık Anabilim Dalı, Ankara, aycakcay@gmail.com. https://orcid.org/0000-0002-2437-095X

Burada sunulan çalışma Hacettepe Üniversitesi, Güzel Sanatlar Enstitüsü, İç Mimarlık Anabilim Dalı bünyesinde hazırlanan “Arkeolojik Alanlarda Yerinde Sergileme Kavramı: Phaselis Hadrianus Kapısı Örneği”" başlıklı Yüksek Lisans Tezi'nden yararlanılarak üretilmiştir.
} 


\section{Giriș}

Taşınmaz kültür varlıkları veya mimari yapıların mevcut konumlarında çeşitli ekipmanlar ve yöntemler yardımıyla bilgilendirme ve teşhir amaçlı sergilenmesi yerinde sergilemenin temelini oluşturmaktadır. Yerinde sergileme, taşınmaz materyal kültür kalıntılarının yerinde -in situkorunması, sergilenmesi ve ziyaretçilere tanıtılması amacıyla uygulanmaktadır. Yerinde sergileme kavramında sergilenecek eserin mevcut konumuyla çevresinin ilişkilendirilmesi yerinde sergileme yöntemine teknik ve uygulama özelinde yön veren, yapılacak çalışmalarda belirleyici rol oynayan bir etkendir. Ayrıca ziyaretçilerin eserlerle olan ilişkisi ve eserleri algılamaları sergide öncelikli olmalıdır. Alanın özellikleri göz önünde bulundurularak ziyaretçilerin kolay, verimli ve kalıcı nitelikte bilgiye ulaşmaları sağlanmalıdır.

Kullanılacak olan sergileme yöntemi; çalışmanın yapılacağı materyal kültür kalıntısının veya yapının özelliklerine, konumuna, sergilendiği yere, eserle ilgili literatür çalışmalarına ve ziyaretçilerin profiline bağlıdır. Bu etkenler dikkate alınarak organize edilecek sergileme yöntemiyle verimli bir bilgi akışı sağlanacaktır. Sergilemede başarılı bir etkileşimin öncelikle kolay, ilgi çekici ve eğlenceli olması gerekmektedir, yaklaşılabilirlik anahtardır (Hughes 2015, 162). Sergideki planlama, tasarım, yönetim ve değerlendirme aşamalarının tamamında ulaşılan başarı düzeyi eserlere ve eserlerin bulundukları alanlara ilgiyi artırmakta, toplumun kültürel miras konusunda duyarlı davranmasına ve bilinçlenmesine katkı sağlamaktadır. Toplumda oluşturulacak farkındalığın, bilgilendirme ile dolayısıyla bilinçlendirme ile mümkün olacağı düşünüldüğünde etkili sergileme, kültürel mirasın korunmasını sağlamaya yönelik en önemli adımlardandır. Pek çok arkeolojik alanın karşılaştığı sorunlara ilişkin kamu bilincini artırmak, arkeolojik alanın korunma ve yönetimine ilişkin profesyonel tartışmalara katkıda bulunmak amacıyla konuyla ilgili bilgilerin yayılması kuvvetle teşvik edilmektedir (Matero et al. 1998, 136).

Yerinde sergileme yöntemi ile sergilenecek olan eserler, dış etkenlere maruz kalmaları nedeniyle tahrip olma tehlikesiyle karşı karşıyadır. Karbon, tuz, asit benzeri kimyasal etkenler, mantar, liken, ağaç kökleri vb. doğal oluşumların eserlere verdiği zararlar bakımından biyolojik etkenler ve bunun yanı sıra insan kaynaklı fiziksel etkenler materyal kültür kalıntılarının maruz kaldığ 1 tahribat unsurlarındandır. Bu etkenler içerisinde süreç bağımlı olarak en hızlı unsurlar doğal afetler veya vandalizmden kaynaklanan tahribatlardır. Eserlerin yerinde sergilenebilmesi için eserin özelliklerine bağlı olarak koruma önlemlerinin alınmış olması gerekmektedir. Yerinde sergilenecek eserlerin korunma durumlarına uygun biçimde bilimsel yöntemler ışığında uygun görülen çalışmalarla sergileme öncesinde koruma, konservasyon ve restorasyon uygulamaları yapılmaktadır. Böylelikle yerinde sergilenecek eserler, sergileme aşamasına kadar korumanın gerekliliklerini sağlamaktadır. Bu kapsamda yerinde sergilemenin aşamaları düşünüldüğünde doğru bir uygulama, korumanın gerekliliklerini sağlayarak kültürel miras eserlerinin geleceğe aktarılmasını sağlayan bir uygulamadır.

Tablo 1. Yerinde Sergilemenin Gereklilikleri ve İlgili Olduğu Kavramlar

\begin{tabular}{|l|l|}
\hline \multicolumn{1}{|c|}{ Yerinde Sergilemenin Gereklilikleri } & \multicolumn{1}{c|}{ İlgili Kavramlar } \\
\hline a. Boyutsal Gereklilikler & Fizyoloji, antropoloji ve ergonomi \\
\hline b. Teknik Gereklilikler & $\begin{array}{l}\text { Doğal/Yapay aydınlatma, malzeme, akustik, } \\
\text { havalandırma, güvenlik, yangın, afet yönetimi }\end{array}$ \\
\hline c. Estetik ve Algısal Gereklilikler & $\begin{array}{l}\text { Biçim, Form, renk, vurgu, kontrast, ritim, } \\
\text { sicaklık, nem, akustik, duyusal efekt }\end{array}$ \\
\hline
\end{tabular}

Yerinde sergileme yönteminde diğer sergi türlerinde olduğu üzere sergi öncesi hedeflenen başarı düzeyine ulaşılmasında mekansal özellikler ve gereklilikler belirleyici rol oynamaktadır. Sergi türlerine bağlı değişiklik görülse de sergilerin teknik, fiziksel, algısal, boyutsal, estetik 
gereklilikleri ve ihtiyaç duyulacak altyapısının sağlanması gerekmektedir. Ziyaretçilere konforlu, erişilebilir, anlaşılabilir bir alan sunulmalı, sergi düzeni insan-mekan-nesne etkileşimi üzerinden kurgulanmalıdır.

Çalışmada yerinde sergileme yönteminin arkeolojik alanlardaki uygulamalarına bir örnek sunulmuştur. İncelenen arkeolojik yapı Phaselis'te bulunan Hadrianus Kapısı'dır. Kentin en yoğun kavşak noktasında yer alan yapı, bir giriş kapısı niteliğindedir ve antik dönemde olduğu gibi Güney Liman yönünden gelen ziyaretçiler günümüzde de bu noktadan geçerek kente giriş yapmaktadır. Hadrianus Kapısı'nın bulunduğu alanda yürütülen çalışmalarda ziyaretçilerin büyük bir kısmının kapıyı algılayamadıkları gözlemlenmiştir. Bu durum monümental yapının ayak kaideleri haricinde tamamen yıkılmış durumda olması ve sergilemedeki eksikliklere bağlidır. Zira kapıya ait yüzlerce bloğun alana dağılmış durumda olması ziyaretçiler tarafından herhangi bir arkeolojik yapıyla ilişkilendirilememekte ve bunun yanı sıra antik kentin uğrak noktası olan bu alan karmaşık, düzensiz bir algı yaratmaktadır. Çalışmada Hadrianus Kapısı özelinde sunulan yerinde sergileme önerisiyle ziyaretçilerin farkındalık kazanarak arkeolojik doku hakkında bilgilendirilmesi, tahribata neden olabilecek bilinçsiz davranışların önüne geçilmesi hedeflenmektedir. Bu kapsamda Phaselis Hadrianus Kapısı'na ait yerinde sergileme çalışmasıyla antik kentin mevcut arkeolojik dokusu bozulmadan, etkili ve ziyaretçilerin dikkatini çeken bir sergi deneyimi yaşatılması amaçlanmaktadır.

\section{Materyal ve Yöntem}

Çalışmanın konusu arkeolojik alanlarda yerinde sergileme yönteminin uygulandığı, Phaselis Antik Kenti'nde bulunan Hadrianus Kapısı'dır. Roma imparatoru Publius Aelius Traianus Hadrianus'un kenti ziyaret etmesi sebebiyle MS 130-131 y1llarında imparatorun kente denizden giriş yaptığı anıtsal bir kapı niteliğindedir (Tüner Önen 2008, 321). Aynı dönemde inşa edilmiş Attaleia (Antalya), Perge Hadrianus Kapıları benzer mimari özellikler taşımaları ve daha iyi korunmuş olmaları nedeniyle, tez çalışmasının konusu olan Phaselis Hadrianus Kapısı'nın restitüsyon ve restorasyon önerilerinin geliştirilmesine ve üç boyutlu modeller üzerinden maketinin tasarlanmasına referans olmuştur (Attaleia Kent Kapıları için bk. Okatan 2004).

Hadrianus Kapıs1, Phaselis Antik Kenti'nde Merkezi Liman ve Güney Limanı birbirine bağlayan ana cadde aksında, Güney Liman'a geçiş konumunda bulunmaktadır. Yapı, tek kemerli anıtsal bir giriş kapısı niteliğindedir. Kapının yüksekliği $8.80 \mathrm{~m}$, genişliği $10.30 \mathrm{~m}$ ve derinliği ise 3 m'dir. Kapı günümüze ayak bölümleri hariç tamamen yıkılmış durumda ulaşmıştır (Fig. 1).

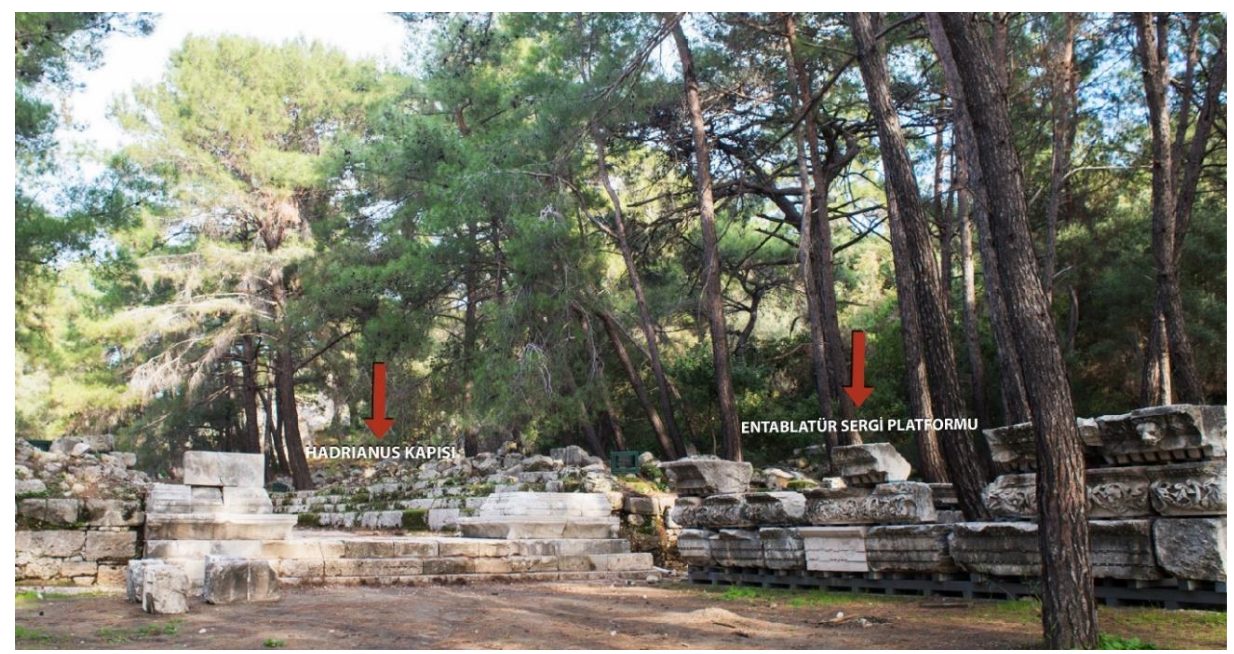

Fig. 1. Günümüzde yıkılmış durumda olan Hadrianus Kapısı'nın ayak blokları ve sağda entablatür kısmına ait sergileme platformu (Kişisel arşiv). 
Yaklaşık 2000 yıllık süreç içerisinde geçirdiği yangın, deprem vb. doğal etkenlere maruz kalmasının yanı sıra insan kaynaklı tahribat nedeniyle de blokları eksik durumdadır, kalan blokları ise iyi korunamamıştır. Yapıya yönelik kapsamlı koruma çalışmaları 2017 yılında başlamıştır. Alan düzenlemesi ve birbirine ait olduğu tespit edilen blokların restorasyon işlemleri sonrasında entablatür kısmına ait mevcut bloklar tasarlanan konstrüksiyon üzerine yerleştirilerek sergilenmektedir (Arslan \& Tüner-Önen 2019, 459).

Hadrianus Kapısı bloklarının büyük bir kısmının eksik olmasına karşın yapının özgün mimari dokusunu taşıyan nitelikli bloklarının büyük bir kısmı günümüze kadar korunagelmiştir (Fig. 2). Bu durum yapının fiziksel olarak ayağa kaldırılmasını mümkün kılmamaktadır. Ancak alanda korunan nitelikli bloklar yapının mimari özellikleri ve bezeksel nitelikleri hakkında yeterli bilgiyi sağlamaktadır.

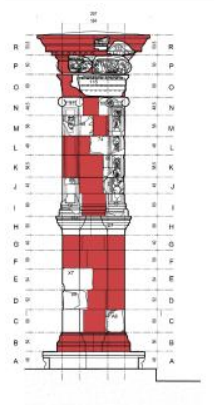

KUZEYBATI CEPHESI
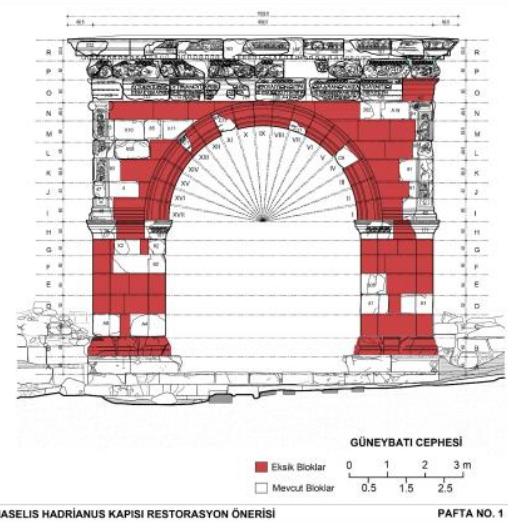
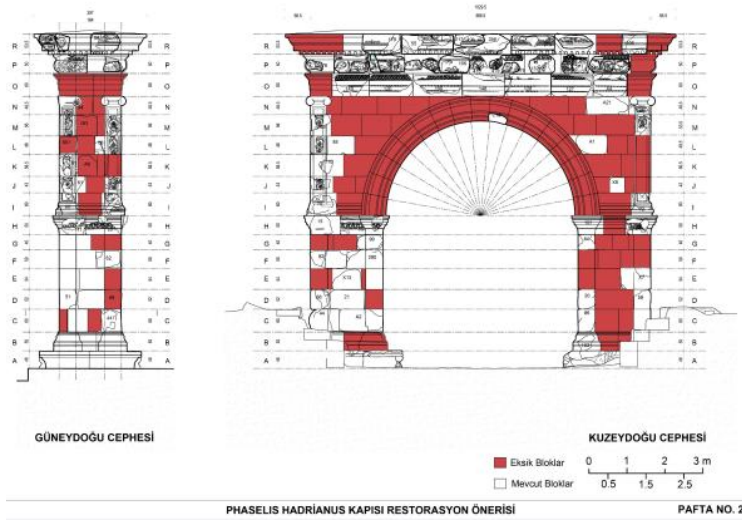

Fig. 2. Hadrianus Kapısı'nın mevcut ve eksik bloklarının durumu (Kişisel arşiv)

Alandaki düzenleme çalışmaları, iki ve üç boyutlu belgeleme çalışmaları sırasında elde edilen bilgiler ve ulaşılan bulguların ziyaretçilere aktarılması amacıyla etkili bir sergilemenin gerekliliği ortaya çıkmıştır. Ziyaretçiyi sergi sürecine dahil ederek aktif katılımcı olması, sergi elemanlarını deneyimlemesi hedeflenmiştir. Deneyimsel alanların yapının işlevine göre yapılandırıldığı mekânlar akılda kalıcı olmaktadırlar (Durukan 2020, 208). Bu bağlamda kapının yerinde sergilenmesi ve gerekli sergileme elemanları hazırlanarak ziyaretçilerin yapıyı ve yapının bulunduğu alanı çevresiyle birlikte fark edebilmeleri sağlanacaktır. Böylelikle alandaki bloklar arkeolojik bir yapının elemanları olarak idrak edilecek ve farkındalık yaratılarak eserlerin korunmasına katkı sunulacaktır. Sergileme elemanları konumlandırılırken ziyaretçilerin kent içinde ve yapının bulunduğu alandaki dolaşımları dikkate alınacaktır.

Yapının bulunduğu konum kent içindeki ziyaretçi sirkülasyonunun en yoğun olduğu alanların başında gelmektedir. Hadrianus Kapısı'na ziyaretçiler üç farklı güzergahtan ulaşabilmektedir. En yoğun ziyaretçi akışı, su kemerlerinin (aquaeductus) önünde bulunan otopark alanından başlayarak kent merkezine doğru uzanan yak. 350 m uzunluktaki güzergahtır. Kapının bulunduğu alana akışı sağlayan diğer güzergah, Güney Liman'a bağlanan yak. $500 \mathrm{~m}$ uzunluktaki toprak yoldur (Fig. 3).

Ziyaretçilerin deniz yoluyla geldiklerinde kullandıkları güzergah ise Güney Liman'a konumlandırılan ahşap iskele ile sağlanmaktadır. Kapının hemen önünde yer alan bu noktada, deniz yoluyla gelen ziyaretçiler için bilet gişesi bulunması ve kent içi sirkülasyonun kavşak noktasında yer alması yoğunluğa sebebiyet vermektedir. Söz konusu yoğunluk gerek yap1 gerek kent için tehdit oluşturmaktadır (Göktuğ et al. 2017). 


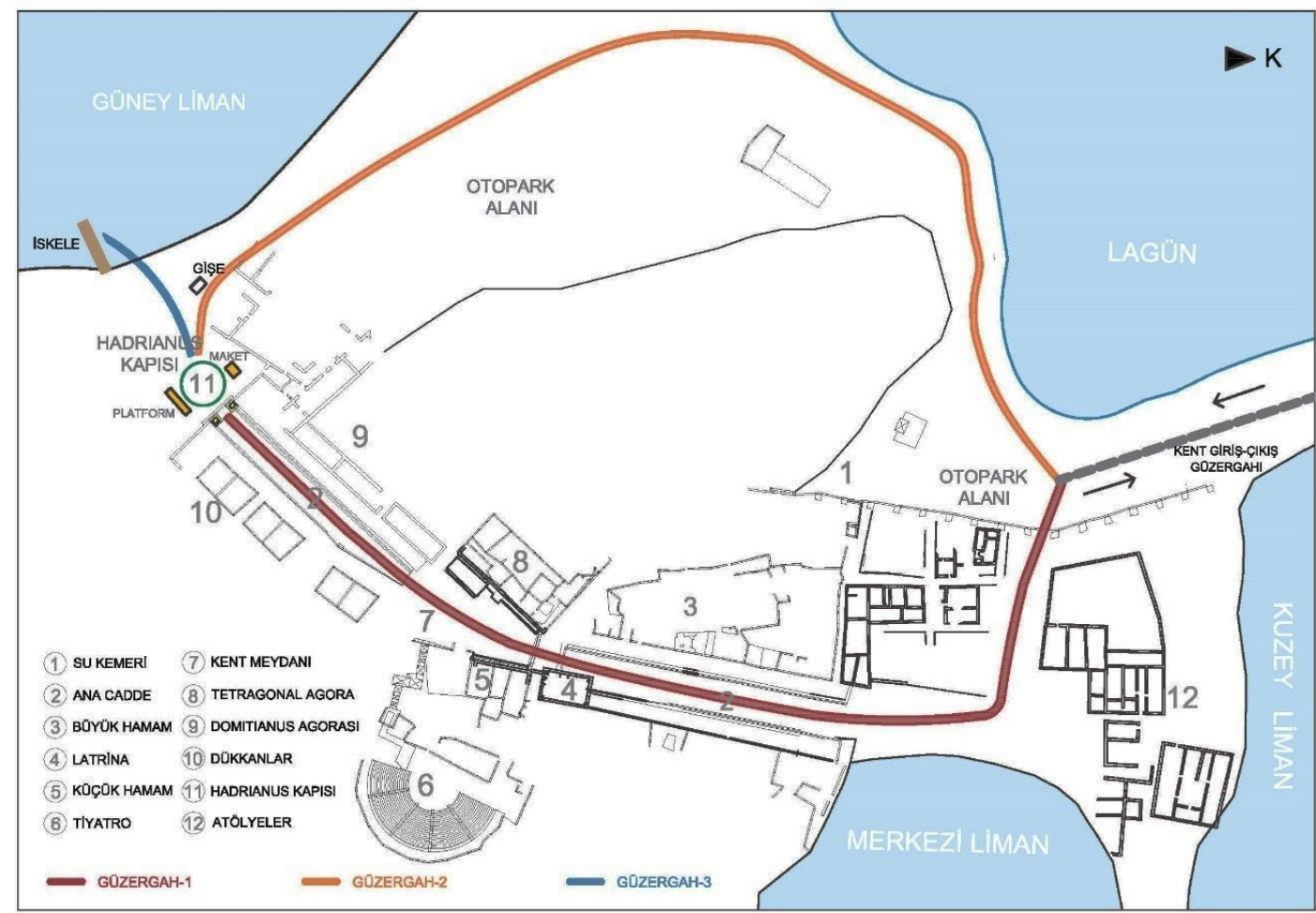

Fig. 3. Kent içerisinde ziyaretçilerin Hadrianus Kapısı'na ulaşım güzergahları (Kişisel arşiv)

Ziyaretçilerin büyük bir kısmının Hadrianus Kapısı'nın bulunduğu alandan geçerken karşılaştıkları yüzlerce bloğun monümental bir kapıya ait olduğunu algılayamadıkları gözlemlenmiştir. $\mathrm{Bu}$ durum sergileme ve bilgilendirme elemanlarının olmayışı ve yapının ayakları hariç yıkılmış durumda olmasıyla ilişkilendirilebilir. Tahrip olmuş yapının yerinde sergileme metodu; belgeleme çalışmaları, çizimler, sayısal görüntüleme verileri üzerinden üretilen iki ve üç boyutlu modellemeler ve yerinde sergileme elemanları ile desteklenerek ele alınacaktır. Bu kapsamda, alanda bulunan yapıya ait blokların her geçen yıl daha fazla tahribata maruz kalmaması amacıyla yerinde koruma ve sergileme çalışmaları yürütülmüştür. Sergilemenin arkeolojik alanlarda bir yaklaşımı niteliğindeki bu çalışma içerisinde, sergilenen yapının korunma durumuna ve sergileme yapılan alanın özelliklerine göre bir yöntem izlenmiştir. Bunu yaparken alanda düzenleme, tasnif, belgeleme çalışmaları yürütülmüş ve yerinde sergileme alanları belirlenmiştir. Entablatüre ait platform, bilgilendirme panoları, perspektif bakış panosu (wireframe) ve üç boyutlu yazıcı ile üretilmiş ölçekli maket alanda sergilenecektir (Fig. 4). Sergileme elemanlarının içeriğinde ve üretiminde teknolojik metotların kullanılmasının yanı sıra bütün sergi bileşenlerinin tek bir yapıda kullanılması Hadrianus Kapısı'nın sergileme yöntemini benzer örneklerden farklı kılmaktadır.

Alanda kullanılacak bilgilendirme panoları yapının mimari özelliklerini, tarihçesini, kent içerisindeki önemi hakkında verileri anlaşılır biçimde ifade edebilecek bir sergi elemanı olarak düşünülmüştür. Bilgilendirme panolarına yerleştirilen karekod aracılığıyla Phaselis Araştırmaları resmi web sitesine (www.phaselis.org) yönlendirilecektir. İlgili bağlantı aracılı̆̆ıyla web sitesinin Hadrianus Kapısı bölümü açılarak burada sunulan dijital içerikler ile üç boyutlu interaktif modellere ve yapı hakkında yapılan tüm çalışmalara ulaşılabilecektir. 


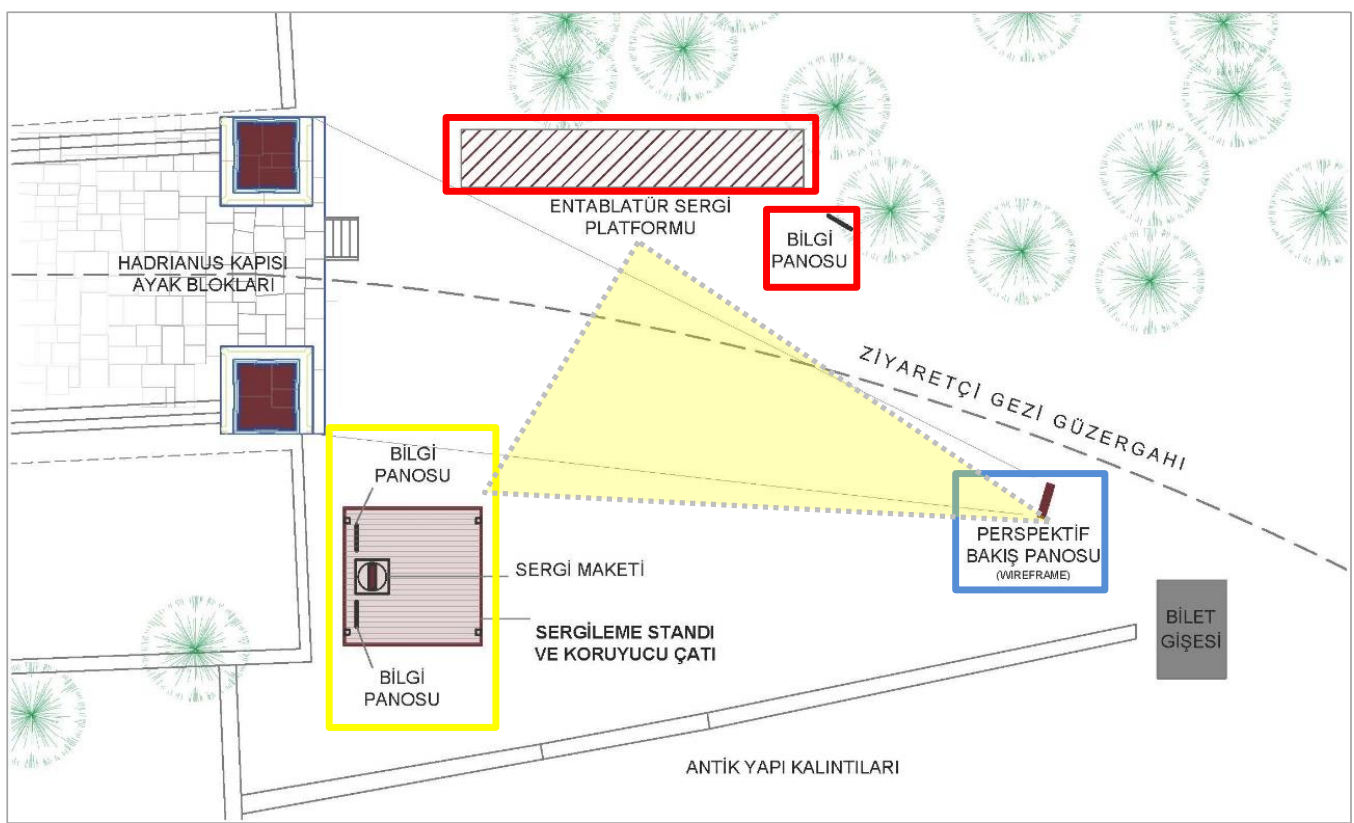

Fig. 4. Hadrianus Kapısı'nın bulunduğu alanda yerinde sergileme elemanlarının yerleşimi (Kişisel arşiv)

Alanda hazırlanacak bilgilendirme panoları dış mekan şartlarına uyumlu malzemelerle, boyutsal ve algısal gereklilikleri sağlayacak şekilde hazırlanacaktır (Fig. 5). Bilgilendirme panoları alanda entablatür platformunun yakınında ve maketin sergileneceği koruyucu çatının altında yer alacaktır. Fotogrametrik modeller ile hazırlanan sayısal veriler aracılığıyla üç boyutlu yazıcıdan üretilen maketin bilgilerini içeren bilgilendirme panosunun yapıdaki yazıt, bezeme vb. detayları içerecek açıklayıcı bilgilerle ziyaretçilere verimli bir sergi deneyimi sağlaması amaçlanmaktadır.

Bilgilendirme Panolarının Sergiye Katkısı:

- Yapının mimarisi ve tarihçesi hakkında bilgi verilmesi,

- Bilimsel ve güncel verilerle bilgilendirme,

- İki ve üç boyutlu içerikler,

- Karekod üzerinden web sitesindeki 3B modellere, yapılan çalışmalara, modern/antik kaynaklara erişim,

- Phaselis Araştırmaları'na ait kurumsal kimlik çalışmaları,

- Kent genelindeki yapılarda yapılacak sergilerde bütüncül tasarıma yön verilmesi.

Alana yerleştirilecek sergi ögelerinden bir diğeri perspektif bakış panosudur. Bu bilgi panosu kapının restitüsyon çizimini perspektiften gösteren çizgisel bir tasarıma sahiptir. Bu tasarımda panonun ayakları arasına sabitlenen ve üzerine yapının restitüsyon çizimi işlenen bir pleksiglas yerleştirilecektir. Böylelikle Hadrianus Kapısı'nın bulunduğu noktaya bu saydam panodan bakıldığında yapı orijinal yerinde, vektörel olarak ayağa kaldırılmış bir formda algılanabilecektir (Fig. 6). Söz konusu pano diğer sergileme elemanlarının bulunduğu alanın dişında, kapıya uzak bir konumda yer alacaktır. Belirlenen bu alan kapıyı belirli bir mesafeden ve perspektiften görebilen, aynı zamanda ziyaretçilerin geçiş noktasına yakın bir lokasyonda durmalıdır. Bu alan bilet gişesinin arka kısmı olarak belirlenmiştir (Fig. 4). 
Perspektif Bakış Panosunun Sergiye Katkısı:

- Ziyaretçilerin sergi alanına yönelimi,

- Yapının çizgisel formda, yerinde (in situ) algilanmas1,

- Kapıyı etrafındaki kalıntılarla karşılaştırarak ölçeklendirebilmesi,

- Ziyaretçilerin kente yönlendirilmesi.

Yerinde sergileme öncesinde uygulanan koruma işlemleri kapsamında, 2019 yılı çalışmalarında yapının entablatür kısmına ait korunmuş üç sıra blok, tasarlanan bir platform üzerine anastylosis yöntemiyle yerleştirilmiştir. Arkeolojik yapıların mevcut parçalarının bir araya getirilerek yerinde sergilenmesinde tercih edilen anastylosis yöntemi, çalışmalar sırasındaki düzensizliği önleyerek yapı elemanlarının bir araya getirilmesiyle yapının anlaşılmasını, yapılacak müdahalelerin kolaylaşmasını ve doğruluğunu sağlamaktadır. Anastylosis, arkeolojik çalışmaların sebep olduğu kaosu, dağınıklığı bir düzene sokmakta, anıtın tahrip edilmeden önceki görünümünü gözler önüne sermektedir (Hueber 1991, 41). Bu kapsamda Hadrianus Kapısı'na ait parçalar restorasyon işlemleri gerçekleştirildikten sonra belirli bir sistematikte yapının bulunduğu alanda belirlenen bir konuma dizilmiştir. Blokların zemin ile temasını engellemek ve stabil bir zemin yaratmak amacıyla platform tasarlanmıștır (Fig. 79). Kapının entablatür ait (geison-sima, friz, arşitrav) korunagelen blokları platform üzerine yerleştirilmiştir.

Teknik gereklilikler kapsamında değerlendirilen ziyaretçi-nesne mesafesi gereği ziyaretçilerin bloklara temasının engellenmesi ve güvenliğin sağlanması amaciyla platformun etrafı ahşap desteklerle çevrilmiştir (Fig. 8).

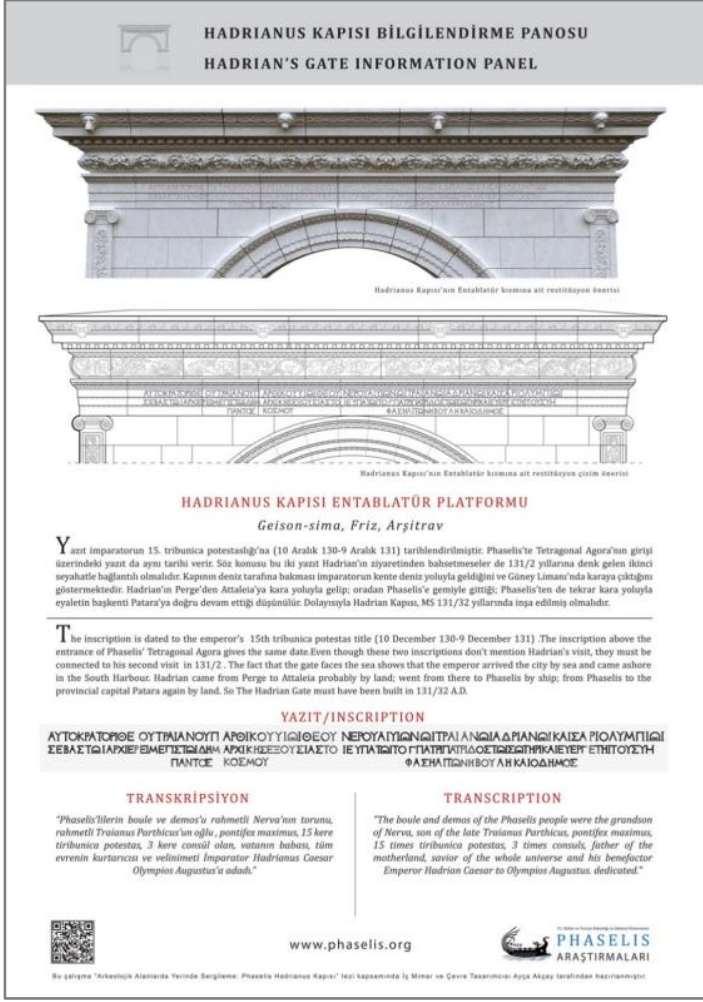

Fig. 5. Alanda sergilenecek bilgilendirme panolarına dair taslak çalışması (Kişisel arşiv)

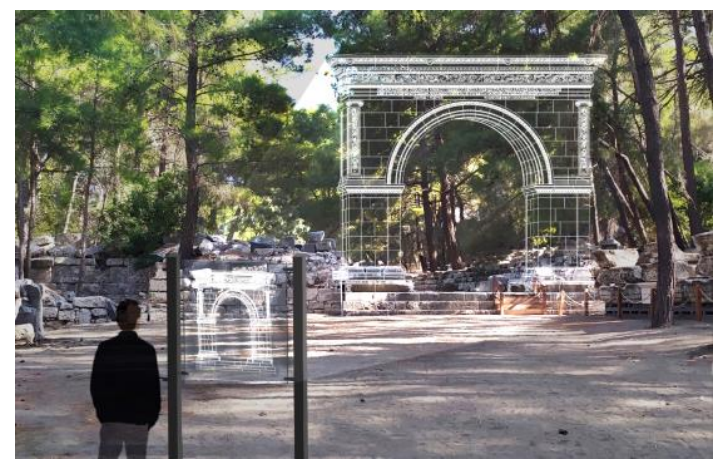

Fig. 6. Ziyaretçilerin Hadrianus Kapısı'nı yerinde algılayabilmeleri amaciyla hazırlanan perspektif bakış panosu (Kişisel arşiv)

$\mathrm{Bu}$ platform ziyaretçilerin yapıyı algılaması ve yerinde sergilemeyi desteklemesinin yanı sıra blokların korunmasını da sağlamaktadır.

Entablatür Platformunun Sergiye Katkısı:

- Nitelikli blokları yapıyla ilişkilendirebilme,

- Yapının bir bölümünün ayağa kaldırılması,

- Yazit ve bezemeleri yakından inceleyebilme,

- Blokların yerinde korunması ve sergilenmesi,

- Ardıl çalışmalarda detaylı incelemelerin veya uygulamaların kolaylıkla yapılabilmesi. 


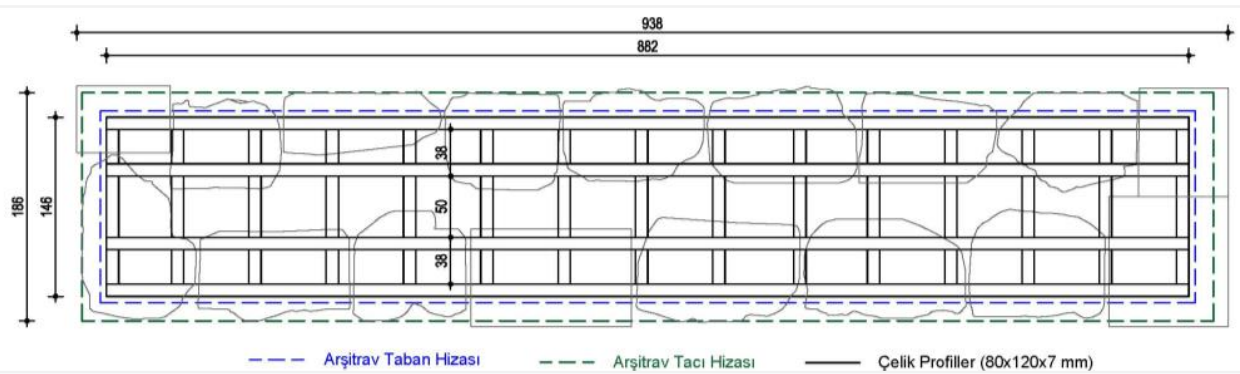

Fig. 7. Entablatür kısmının sergilenmek üzere yerleştirildiği platformun konstrüksiyon şeması

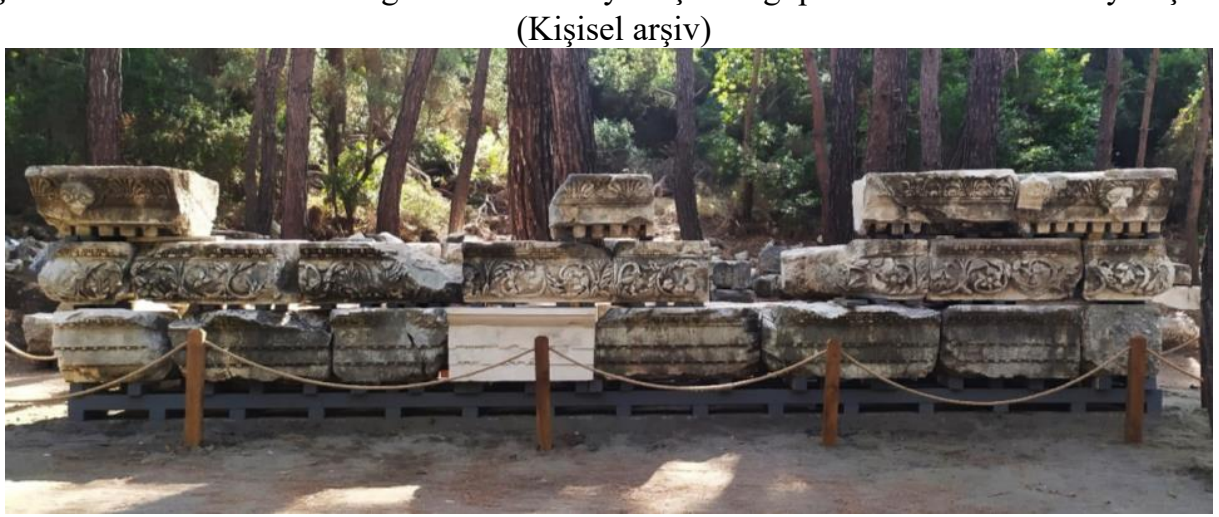

Fig. 8. Entablatür kısmının yerinde sergilenmesi (Kişisel arşiv)

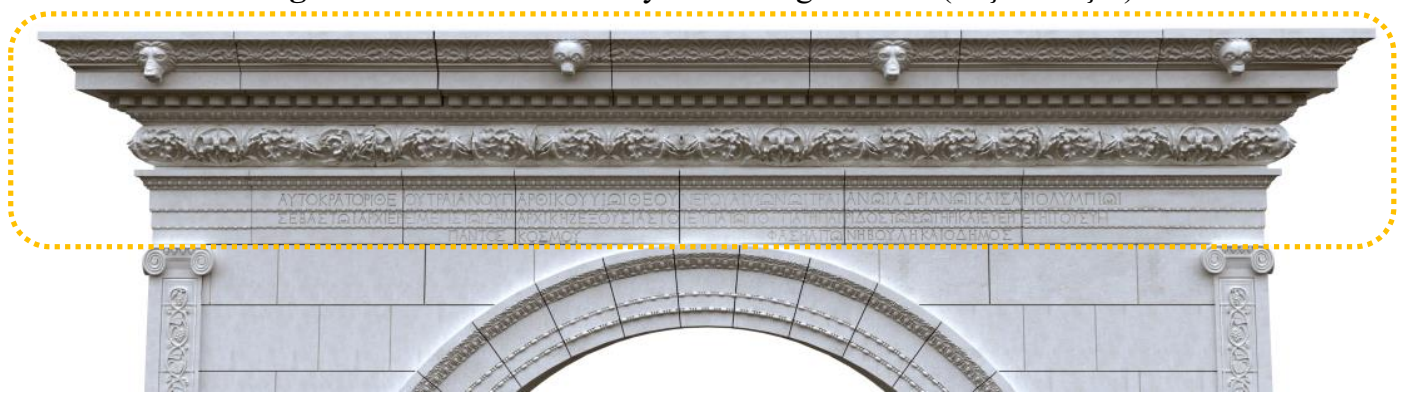

Fig. 9. Entablatür bölümünde sergilenen blokların restitüsyon modelinde görünümü (Kişisel arşiv)

Hadrianus Kapısı'nın restorasyona uygun olmaması nedeniyle ziyaretçiler tarafindan detaylı algılanabilmesi için ölçekli modelinin alanda sergilenebileceği düşünülmüştür. Alandaki çalışmalar ve detaylı belgeleme çalışmaları ile elde edilen veriler yapının dijital ortamda üç boyutlu modelinin üretilmesini sağlamıştır. Bu modeller baskıya uygun hale getirildikten sonra 1/15 ölçekte üç boyutlu yazıcıdan basılmıştır. Alanda sergilenecek maket ile yapının tüm detayları restitüsyon modeline uygun sergilenerek yazıt, bezeme, form yönlerinden algılanabilecektir. Sergileme elemanları aracılığıyla bilimsel çalışmalarda elde edilen veriler ziyaretçilere ulaştırılarak, yorum yapmaya teşvik eden, etkili bir sergileme ve kalıcı bilgilendirme sağlanması amaçlanmaktadır. Sunuş ve bilgi verilmesi, mevcut bilimsel verilerin popüler bir yorumu olarak ele alınmalı ve bu nedenle sürekli güncelleştirilmeli, geçmişi anlama yaklaşımlarının çok yönlülügünün gözetilmesi gerekmektedir (ICOMOS 1990, 3).

Yapının bulunduğu noktada sergilenecek maketin üretimi aşamasında, öncelikle alanda bulunan tüm nitelikli bloklar sayısal görüntüleme metotları ile belgelenmiş ve dijitalleştirilmiştir (Tablo 2). 
Tablo 2. Arkeolojik Alanlarda Ölçekli Model Yardımıyla Sergileme Yöntemi (Kişisel arşiv)

\begin{tabular}{|c|c|c|c|}
\hline \multicolumn{4}{|c|}{ ARKEOLOJIK ALANLARDA ÖLÇEKLI MODEL YARDIMIYLA YERINDE SERGILEME ÇALIŞMALARI } \\
\hline Altyapı Kurulması & Alan Düzenleme & $\begin{array}{c}\text { Üç Boyutlu Yazıcıdan Ölçekli Maketin } \\
\text { Üretimi }\end{array}$ & $\begin{array}{c}\text { Sergiye Yardımcı Elemanların } \\
\text { Hazırlanması }\end{array}$ \\
\hline $\begin{array}{l}\text { - Elektrik } \\
\text { - Internet } \\
\text { - Yangın } \\
\text { - Güvenlik } \\
\text { - Aydınlatma }\end{array}$ & $\begin{array}{l}\text { - Alan Temizliği } \\
\text { - Erişilebilirlik }\end{array}$ & $\begin{array}{c}\text { - Iki ve üç boyutlu belgelemenin } \\
\text { yapılması } \\
\text { - Rölöve, Restitüsyon, Restorasyon } \\
\text { verilerinin hazırlanması } \\
\text { - Katı ve fotogrametrik modellerin } \\
\text { birlesstirilmesi } \\
\text { - Modellerin üç boyutlu yazıcı ile } \\
\text { basılması }\end{array}$ & $\begin{array}{c}\text { - Koruyucu çatı/örtü hazırlanması } \\
\text { - Bilgilendirme panolarının iki ve üç } \\
\text { boyutlu verilerle tasarlanması } \\
\text { - Wireframe pleksiglas çerçeve, AR, VR, } \\
\text { karekod uygulaması gibi interaktif } \\
\text { uygulamaların kurulması }\end{array}$ \\
\hline
\end{tabular}

Hadrianus Kapısı'nın 3B yazıcı ile üretilecek maketinin oluşturulmasında katı modelleme yöntemiyle, yapı blokları orijinal bezemelerine sadık kalarak hazırlanmaya çalışılmıştır (Fig. 12). Ancak bitki bezemesi ve hayvan figürü gibi organik formda betimlemeler taşıyan bloklarda, katı modelleme yöntemiyle birebir aynı formu vermek mümkün olmamıştır. Bu kısıtlamayı aşmak için sayısal görüntüleme metotlarından fotogrametriye başvurulmuştur (Fig. 10-12). Fotogrametri metodu nesnelerin belirli açılardan bir dizi fotoğrafının kaydedilmesi sonucu elde edilen görüntü verilerinin işlenmesi ile üç boyutlu modellerinin elde edildiği bir yöntemdir (Arkeolojik materyallere ilişkin benzer fotogrametri uygulamaları için bk. Akçay - Gürel 2018, Gürel et al. 2019). Elde edilen bu sayısal modeller üzerinden yapıların ölçümleri yapılabilir, restorasyon önerileri, kesitleri hazırlanabilir ve üç boyutlu yazıcıdan maketleri üretilebilir. Bu kapsamda Hadrianus Kapısı'nın alanda bulunan nitelikli bloklarına ait fotogrametrik veriler 3B modelleme çalışmaları sırasında altlık olarak kullanılmıştır.

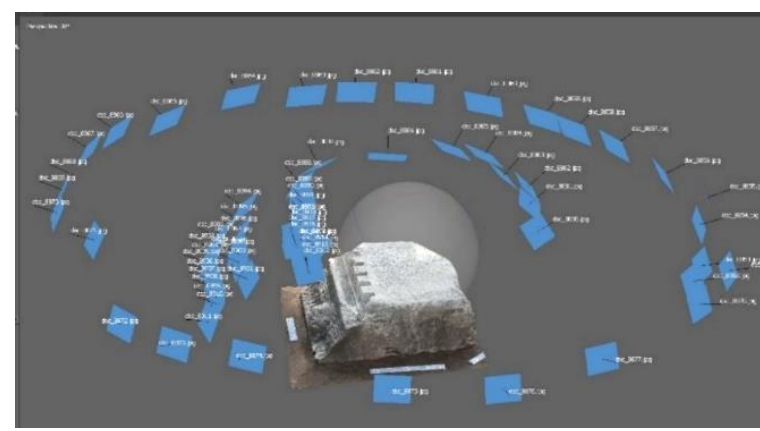

Fig. 10. Fotogrametri yöntemiyle belgelenen bloğun fotoğraflarının Agisoft Metashape Pro programında birleştirilme aşaması (Kişisel arşiv)

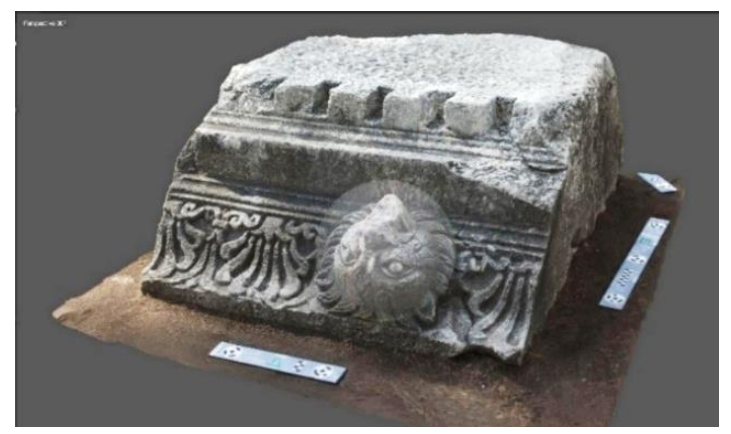

Fig. 11. Orijinal dokusu ile birlikte oluşturulan bloğun fotogrametrik modeli (Kişisel arşiv)
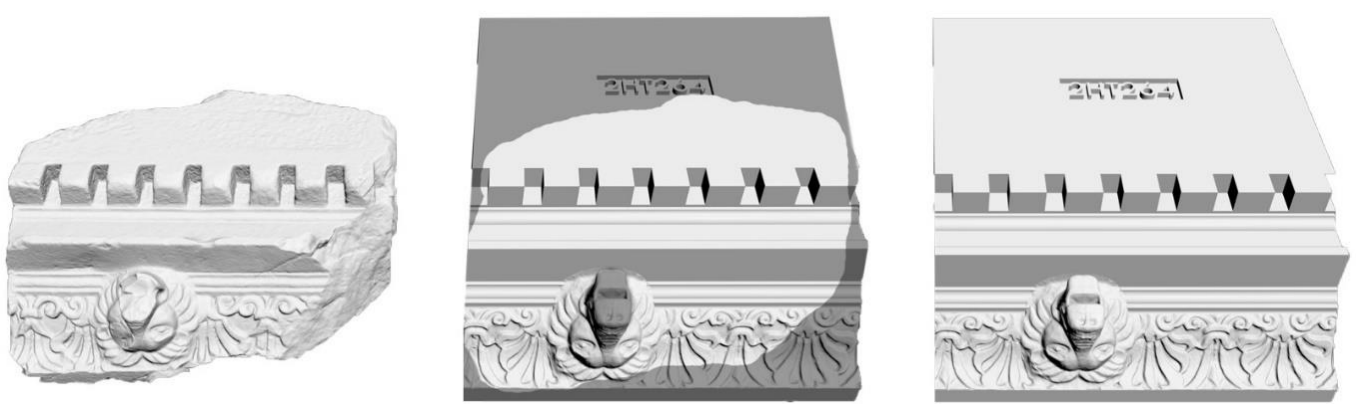

Fig. 12. Maketin üretimi aşamalarında fotogrametrik model, katı modelleme ve organik modelleme desteğiyle üretilen geison-sima bloklarından bir örnek (Kişisel arşiv) 
Yürütülen sayısal modelleme çalışmaları kapsamında elde edilen veriler Hadrianus Kapısı'nın yerinde sergileme elemanlarında kullanılmak üzere, sergi maketinin üretilmesinde, bilgilendirme panolarının görselleştirilmesinde ve internet erişimi aracılığıyla yapıya ait üç boyutlu interaktif modellerin incelenmesinde kullanılacaktır.

Bloklarda görülen tahribat ve kısmi kırıklar, üretilen üç boyutlu modellerde eksikliklere sebebiyet vermiştir. Bu eksiklikleri gidermek ve bitki, çiçek, aslan figürü vb. amorf yapıya sahip nitelikli bloklar organik modellemeyle iyileştirilmiştir. Son olarak kapıya ait niteliksiz bloklar ise katı modelleme yöntemi ile oluşturulmuştur. Bu çalışmalar sırasında katı modellemeler için Autodesk 3Ds Max 2017, organik modellemeler için Pixologic ZBrush 2018 ve fotogrametrik modellerin üretimi için Agisoft Metashape Pro programları kullanılmıştır. Bu modele uygun olarak üç boyutlu yazıcı ile maketin üretimi yapılmıştır (Fig. 13-15).

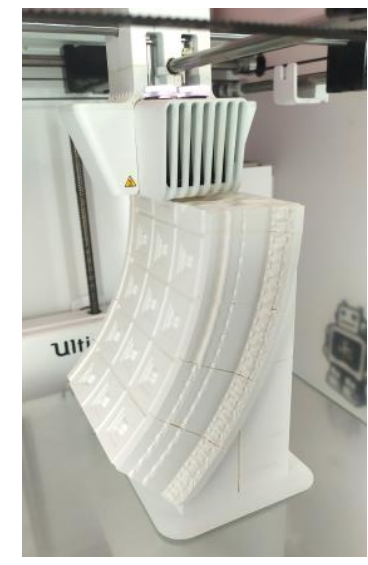

Fig. 13. Üç boyutlu yazıcıda üretim aşaması

(Kişisel arşiv)

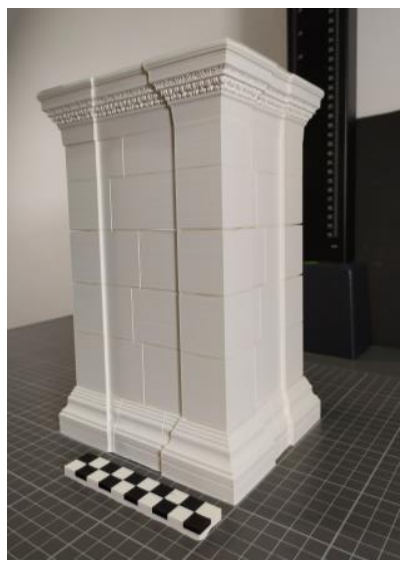

Fig. 14. Ayak bloğunun tamamlanmış hali (Kişisel arşiv)

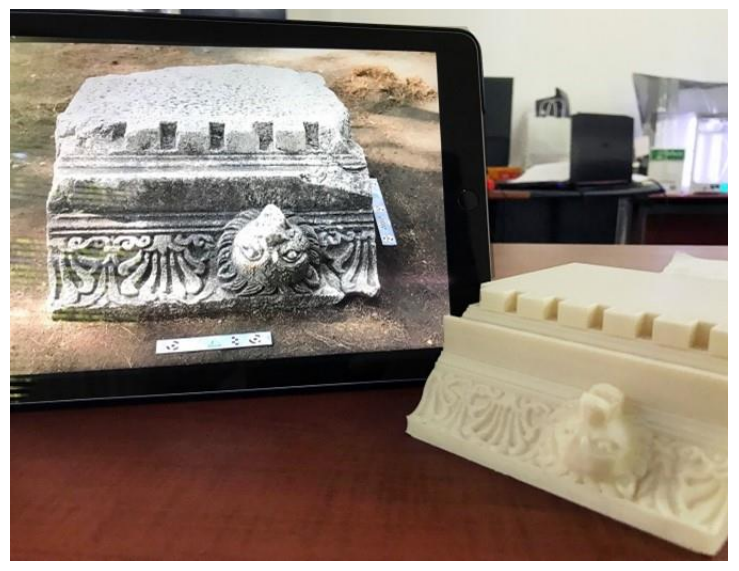

Fig. 15. Geison bloğunun alandaki fotoğrafi ve baskısının karşılaştırılması (Kişisel arşiv)

Maketin üretiminde Ultimaker 3 Extended marka/model üç boyutlu yazıcı kullanılmıştır. maketin boyutsal, estetik, algısal, teknik gereklilikleri ve bloklarda yer alan detayların algılanabilmesi için 1/15 ölçek tercih edilmiştir. Baskı malzemesi olarak geri dönüşebilen (filament) PLA (Polilaktik Asit) tercih edilmiştir.

Üç Boyutlu Yazıcıdan Üretilen Maketin Sergiye Katkısı:

- Maket yardımıyla yapının detaylarının algılanması,

- Yapının kütlesel formunun anlaşılması,

- Yapının orijinal halinin nasil olduğu,

- Cephedeki detayların hassas baskı tekniği ile anlaşılabilmesi.

Maketin üretiminde hazırlanan üç boyutlu modeller yardımıyla dijital görselleştirme çalışmaları yapılmıştır. Elde edilen tüm yapı elemanlarına ait modeller birleştirilerek dijital restitüsyon modeli hazırlanmıştır (Fig. 16). Böylelikle ziyaretçiler mobil cihazlarından bilgilendirme panolarındaki karekod aracılığıyla veya Phaselis Araştırmaları resmi web sitesi üzerinden yapının görselleştirme çalışmalarına erişebileceklerdir. 


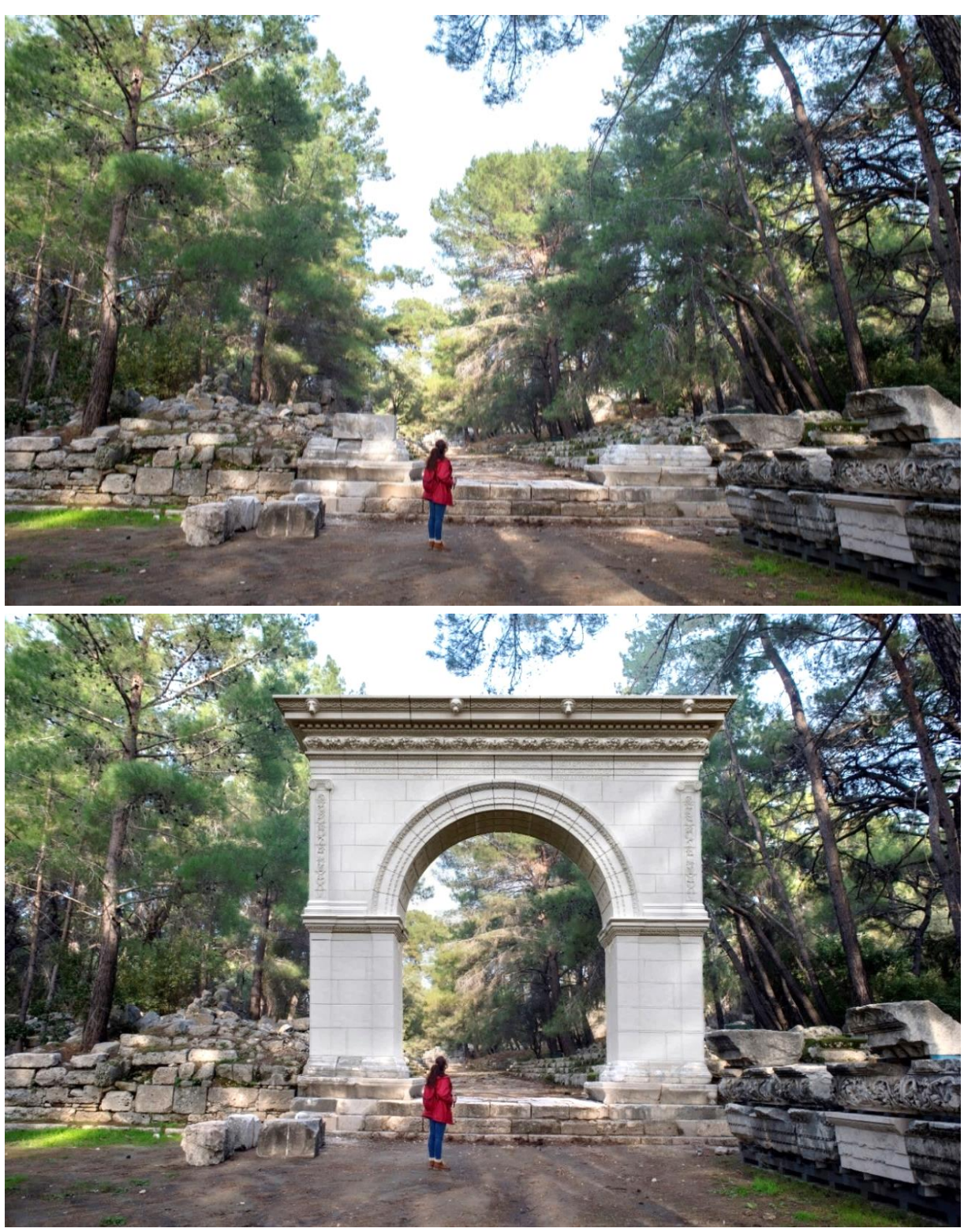

Fig. 16. Hadrianus Kapısı dijital görselleştirme çalışmaları (Kişisel arşiv)

Çalışmada hazırlanan iki ve üç boyutlu restitüsyon önerileri kapsamında nitelikli blokların konumu, fotoğrafi, çizimleri, tahribat düzeyleri, restorasyon ve restitüsyon bilgileri, üç boyutlu modelleri ile üç boyutlu yazıcıdan alınan baskıların detayları vb. belgeleme kayıtları detaylı olarak envanter paftaları halinde hazırlanmıștır. Bu paftalar çalıșmanın temel amacını teșkil eden yerinde sergilemenin içeriğinin olușturulması, restitüsyon ve restorasyon önerilerinin desteklenmesi ve yapıya ait ardıl çalıșmalarda yardımcı olması amacıyla kültürel mirasın korunması, aktarılması hassasiyetiyle hazırlanmıștır (Hadrianus Kapısı'na ait envanter paftaları için bk. Akçay 2020).

Hadrianus Kapısı'nın yerinde sergilenmesi çalışmaları kapsamında üretilen maketin sergilenmesi amaciyla arkeolojik dokuyu bozmayacak materyallerle oluşturulmuş koruyucu bir strüktür tasarlanmıştır. Bu tasarım iki ana kriter etrafında kurgulanmıştır. İlk kriter ziyaretçinin maketi incelerken yapıdan ve bulunduğu alandan soyutlanmaması, ikinci kriter ise dış mekan şartlarından izolasyonun sağlanmasıdır (Fig. 17-18). Koruyucu çatı diğer sergi elemanlarına 
uyumlu biçimde çelik strüktür üzerine levhalar sabitlendikten sonra yalıtımlı membranın uygulanmasıyla oluşturulmuştur. Maketin bulunduğu sergi platformu ise sergileme yöntemlerinin gerekliliklerine uygun şekilde tasarlanan bir kaide üzerinde, cam hazne içerisinde sergilenmektedir. Kaide ve hazne yüksekliği boyutsal, teknik, estetik gereklilikler ve aydınlatma elemanlarının yaratacağı yansımanın olumsuz etkileri düşünülerek ayarlanmıştır. Maketin yapım tekniklerinin ve yapı hakkında bilgilerin yer aldığı bilgilendirme panoları maketin hemen yanında bulunmaktadır. Bu pano diğer sergi elemanlarında olduğu gibi Türkçe ve İngilizce olarak hazırlanmıştır. Kullanılan malzemeler ziyaretçilerin algısını bozmayacak malzeme ve minimum müdahaleyle, yalın bir tasarımla, antik dokuya uygun olarak seçilmiştir.

Maketin sergileneceği koruyucu örtünün konumu çevresel faktörler ve kent içerisindeki sirkülasyon yoğunluğu göz önüne alınarak kapının bulunduğu alanın hemen yanına konumlandırılmıştır. Bu etkileşim noktası, kent içerisinden gelen ziyaretçileri ana cadde üzerinden durağan bir ilerleyiş sonucu kapının bulunduğu noktaya ulaştıklarında genişleyen alanın sağ tarafında karşılamaktadır. Sergiler sırasında sirkülasyon akışını etkileyen faktörler arasında yer alan ziyaretçilerin sağa yönelme eğilimi düşünüldüğünde (Bitgood 2000, 4), bu etkenin serginin sirkülasyonu için avantajlı olacağı düşünülmektedir. Diğer iki güzergahtan gelen ziyaretçiler ise kente giriş yaptıkları bu noktaya geldiklerinde sağda entablatür platformunu görecek, solda ise maket için tasarlanan koruyucu strüktürü inceleyebileceklerdir (Fig. 4). Bu bakımdan söz konusu sergileme elemanının sergi akışına pozitif katkı sunacağı öngörülmektedir.

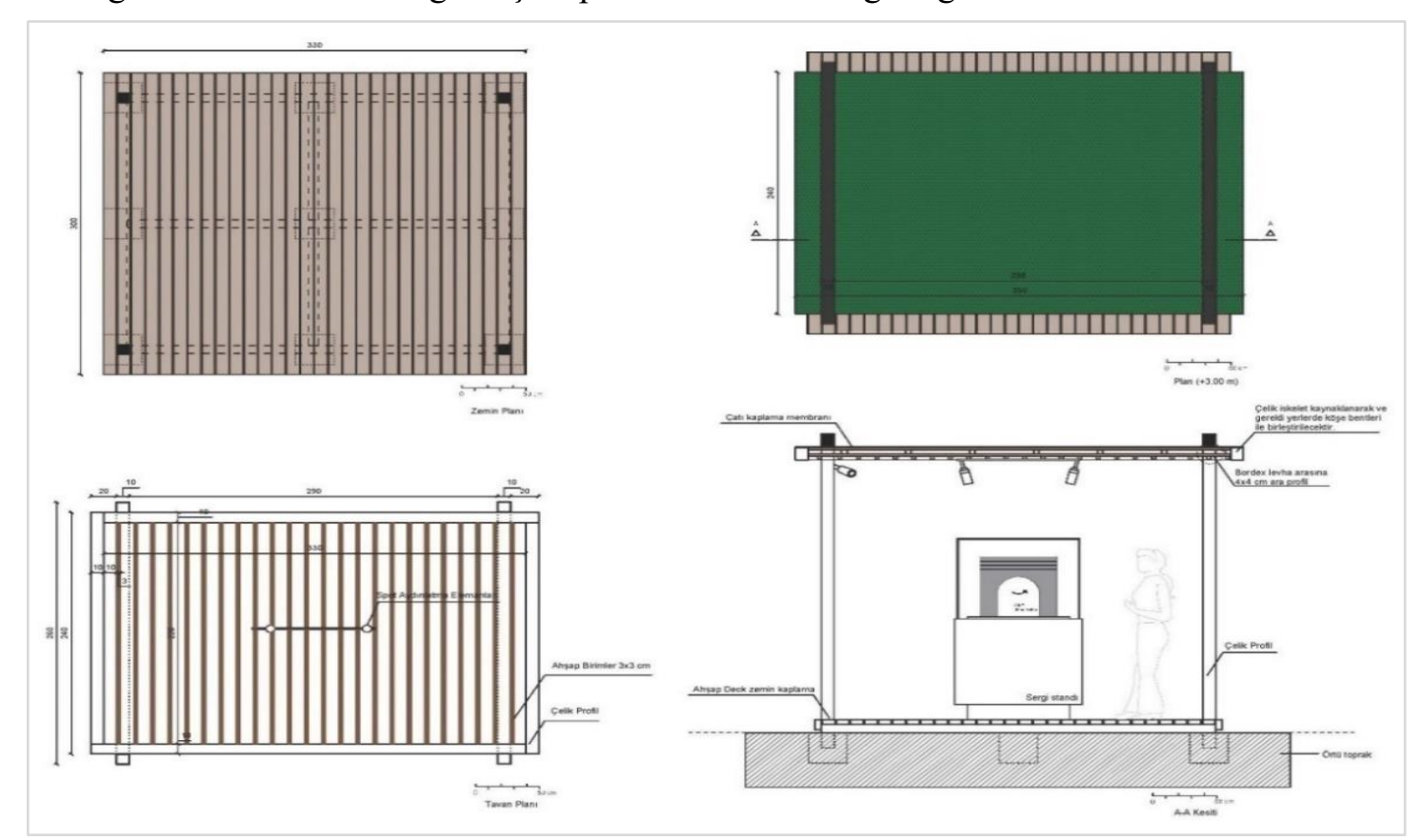

Fig. 17. Sergi maketi için tasarlanan koruyucu çatının çizimleri

Hadrianus Kapısı alanında düzenlenen yerinde sergileme uygulamalarıyla gerek kente deniz yoluyla gelen gerekse halihazırda sirkülasyon halindeki ziyaretçilerin ilgisini sergi elemanlarına çekerek arkeolojik dokuya odaklanmalarının sağlanması hedeflenmektedir. Böylelikle ziyaretçilerin yapının bir giriş kapısı niteliği taşıdığını fark etmeleriyle ana cadde üzerinden kente doğru yönelme eğilimi artacaktır. Yerli/yabancı ziyaretçiler yapının bulunduğu alana geldiklerinde bilgiye ulaşmalarındaki adımlar sırasıyla şu şekilde kurgulanmıştır: İlk aşamada, sergi alanının giriş kısmına konumlandırılan perspektif bakış panosu ile ziyaretçilerin yapıyı vektörel formda algılayabilmeleri ve ilgilerinin sergi alanına çekilmesi sağlanacaktır. 


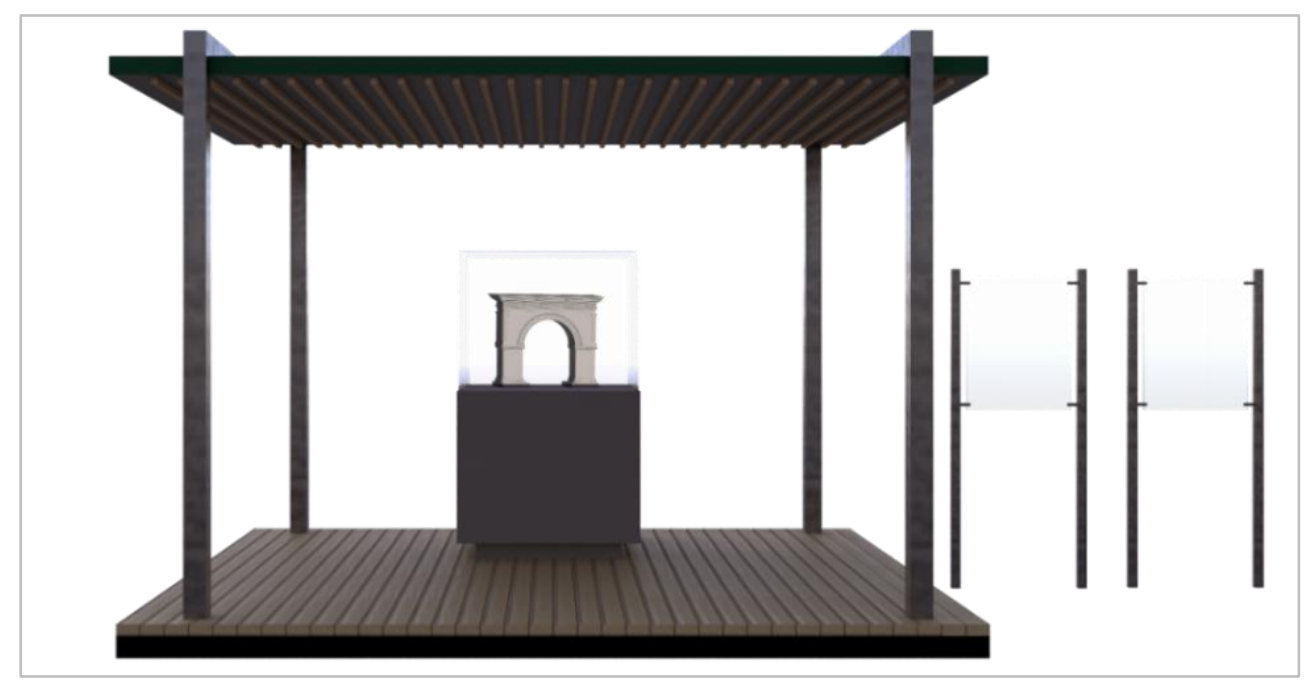

Fig. 18. Yapının bulunduğu alanda tasarlanan sergi elemanları

İkinci aşamada, yapının entablatür bloklarının sergilendiği platforma ulaşılarak kapıya ait orijinal blokların incelenmesi ve bilgi panolarıyla bu bölüme ait mimari bilgiler ve çizimler yardımıyla yapı kısmen algılanmaya başlanacaktır. Üçüncü aşamada ise sergi standına ulaşarak maketin ve yanındaki bilgi panolarının incelenmesiyle yapıyı bir bütün olarak algılayabilecekler ve mimari detaylarını gözlemleyebileceklerdir. Ziyaretçilerin daha detaylı bilgilere erişmek istemeleri halinde bilgi panolarında yer alan karekod sisteminden mobil aygitları yardımıyla internet sitesine yönlendirilerek, yapı hakkında daha fazla bilgiye ve üç boyutlu modelleri detaylı inceleme firsatına sahip olacaklardır. Tüm bu aşamalarda ziyaretçinin tercih edeceği bilgilendirme elemanları kişilerin ilgi düzeyine ve sergi deneyimine bağlı olarak değişecektir.

\section{Sonuç ve Değerlendirme}

Tarihsel süreç içerisinde ticari faaliyetlerin başlamasıyla birlikte gelişen sergileme kavramı günümüzde ticari amaçlarının yanında kültürel gelişim ve kültürel sürdürülebilirliğin sağlanması açısından farklı boyutlar kazanmıştır. Teknolojik metotların sergileme yöntemlerine ve bileşenlerine eklemlenmesiyle fuarlar, müzeler, galeriler, anıtlar, sit alanları, ticari mekanlarda sergiler düzenlenmektedir. Ziyaretçi odaklı kurgulanan sergiler amaçları doğrultusunda detaylı altyapı sistemleri ve donanımları gerektirmektedir. Sergiler ziyaretçi-mekan-nesne arasındaki çok yönlü bir etkileşimin sonucudur. Sergi çeşitleri fark etmeksizin teknik, boyutsal, estetik ve algısal gerekliliklerin sağlanması sergi deneyiminin başarılı bir şekilde gerçekleşmesinin ilk koşuludur. Tasarımcı ve mimar, aydınlatma, güç kaynă̆ı, havalandırma ve erişim ile ilgili önemli kararların alınmasında çalışmanın en başından itibaren bulunmalıdır (Velarde 2017, 14). Yerinde sergileme konusu bu çalışmada arkeolojik alanlardaki uygulamaları için bir örnek olarak ele alınmış, sergileme teknikleri yönüyle yeni bir yaklaşım sunulmuştur.

Çalışmanın temel problematiğini oluşturan yıkılmış durumdaki Hadrianus Kapısı'nın yoğun ziyaretçi akışına nedeniyle tahribata açık olması ve ziyaretçiler tarafından algılanamaması nedeniyle sergileme gerekliliği doğmuştur. Bu kapsamda öncelikle yerinde koruma çalışmaları yürütülmüş ve yerinde sergileme için gerekli veriler hazırlanmıştır. İlk aşamada tüm blokların iki ve üç boyutlu belgeleme işlemleri gerçekleştirilmiş, fotogrametrik modelleri kaydedilmiştir. Restorasyon ve restitüsyon çizimlerine blokların detayları işlenmiş̧ir. Fotogrametrik modeller katı ve organik modellemelerle üç boyutlu restitüsyon modeli hazırlanmıştır. Bu modeller dijital görselleştirme çalışmalarına ve sergileme elemanlarının içeriklerinin oluşturulmasını sağlamıştır. Elde edilen veriler bu çalışmada kullanılmasının yanında yapının detaylı şekilde envanter- 
lenmesini ve yapıya ait yapılacak ardıl çalışmalara altlık olabilme potansiyeline sahip olması yönüyle önemlidir.

Yerinde sergileme kapsamında yeni teknolojik yaklaşımlar kullanılarak hazırlanan sergileme elemanlarıyla ziyaretçilerin kültürel miras konusunda bilinçlenmesi ve İç Mimarlık ve Çevre Tasarımı disiplini ile ilişkili olan sergileme tekniklerine yeni bir yaklaşım sunması amaçlanmaktadır. Bu çalışmayla yerinde sergilemenin tasarım disiplinleri içerisinde önemli bir yaklaşım olduğu ve olacağı, bu konu hakkındaki yönetmeliklerin benimsenip, tasarım ilkeleriyle araştır1larak öğrenilmesi, bu çalışmadan sonraki uygulamalarda yeni teknolojik metotlarla daha da geliştirilebileceği ve sonucun yeni başlangıçlara, yeni üretimlere referans olması amaçlanmaktadır. Phaselis Antik Kenti'nde yerinde sergilemeye yönelik ilk uygulama özelliği taşıyan bu çalışmanın kentin diğer yapılarında ve/veya diğer arkeolojik sit alanlarında yerinde çok yönlü sergileme çalışmalarına örnek teşkil etmesi hedeflenmektedir. Bu çalışma sonucunda arkeolojik bir yapı, iç mimarlık ve çevre tasarımı disiplini perspektifinden bilimsel metotlarla belgelenmiş ve üç boyutlu görselleștirilmiștir. Yeni teknolojik yaklașımlar kullanılarak sergileme elemanları tasarlanmıştır ve monümental bir yapının hedef kitle tarafından algılanması sağlanmıştır. Ziyaretçilerin kültürel mirasın korunmasına yönelik farkındalığı artırılarak antik kent dokusunun korunmasina katkı sunulacaktır. 


\section{BİBLIYOGRAFYA}

Akçay A. 2020, Arkeolojik Alanlarda Yerinde Sergileme Kavramı: Phaselis Hadrianus Kapısı Örneği. Yayımlanmamış Yüksek Lisans Tezi, Hacettepe Üniversitesi. Ankara.

Akçay A. 2016, Kültürel Miras Araştırmalarında Kullanılan Yeni Teknolojik Yaklaşımlar: Phaselis Yazıtları Örneği. Yayımlanmamış Yüksek Lisans Tezi. Akdeniz Üniversitesi, Antalya 2016.

Akçay A. \& Gürel B. 2018, "Görülenin Ötesine Gitmek: Sayısal Görüntüleme Metotları Işığında Termessos’tan Sütunlu Bir Lahit Üzerine Yeni Değerlendirmeler”. Eds. Murat Arslan-Ferit Baz, Arkeoloji, Tarih ve Epigrafi'nin Arasında: Prof. Dr. Vedat Çelgin'in 68. Doğum Günü Onuruna Makaleler. İstanbul, 1-18.

Gürel B., A. Akçay \& N. Tüner-Önen 2019, "Phaselis Teritoryumu’nda Kolalemis ve Ailesine Ait Khamosorion ve Çiftlik Yerleşimi". Phaselis V, 413-424. http://dx.doi.org/10.18367/Pha.19028

Arslan M. \& Tüner-Önen N. 2019, "Phaselis Kenti’nde 2019 Y1lında Gerçekleştirilen Yüzey Araştırmaları ve Kazı Çalışmaları”. Phaselis V, 425-463. Doi: 10.18367/Pha.19029.

Bitgood S. 2000, "The Role of Attention in Designing Effective Interpretive Labels". Journal of Interpretation Research 5/2, 1-12.

Durukan A. 2020, "Yeniden İşlevlendirilmiş Anıtsal Yapılarda Deneyim Odaklı Tasarım: Antalya Kaleiçi ve Balbey Örneği”". MJH X, 195-210. Doi: 10.13114/MJH.2020.526

Göktuğ T. H., A. Yorulmaz, R. S. Göktürk \& B. Deniz 2017, "Determination of Heavy Metal Pollution at Phaselis Bay (Beydağları Coastal National Park-Turkey) by Analyzing of Soil and Quercus Cupressus L.". 3rd International Congress on Applied Biological Sciences (9-12 Haziran 2017).

Hueber F. 1991, “Arkeolojik Yapıların ve Alanların Koruma ve Restorasyon Sorunları”. Arkeolojik Sit Alanlarının Korunması ve Değerlendirilmesi I. Ulusal Sempozyumu (14-16 Ekim 1991), 37-42.

Hughes P. (2015). Exhibition Design. London 2015.

ICOMOS (1990). Arkeolojik Mirasın Korunması ve Yönetimi Tüzüğü. Çev. Z. Ahunbay. Kaynak: http://www.icomos.org.tr/Dosyalar/ICOMOSTR_tr0574229001536913919.pdf Erişim Tarihi: 08.01.2021

Matero F., K. L. Fong, E. D. Bono, M. Goodman, E. Kopelson, L. McVey, J. Sloop \& C. Turton 1998, "Archaeological Site Conservation and Management: An Appraisal of Recent Trends". Conservation and Management of Archaeological Sites 2, 129-142.

Okatan F. 2004, Attaleia Kent Kapıları. Yayımlanmamış Yüksek Lisans Tezi. Akdeniz Üniversitesi. Antalya.

Tüner Önen N. 2008, Phaselis Antik Kenti ve Teritoryumu. Yayımlanmamış Doktora Tezi. Akdeniz Üniversitesi. Antalya.

Velarde G. 2017, Designing Exhibitions. New York. 